\title{
Syntheses, Characterization, and X-ray Crystal Structure of Binuclear Lanthanide Complexes Assembled with Schiff Base and Acetate
}

\author{
Mbossé Ndiaye-Gueye ${ }^{1}$, Amar Diop ${ }^{1}$, Papa Aly Gaye², Ibrahima Elhadji Thiam, \\ Farba Bouyagui Tamboura ${ }^{3}$ and Mohamed Gaye ${ }^{1, *}$ \\ ${ }^{1}$ Department of Chemistry, University Cheikh Anta DIOP de Dakar, Senegal \\ ${ }^{2}$ Department of Chemistry, University Assane SECK de Ziguinchor, Senegal \\ ${ }^{3}$ Department of Chemistry, University Alioune DIOP de Bambey, Senegal \\ *Corresponding author e-mail: mohamedl.gaye@ucad.edu.sn
}

\begin{abstract}
Herein we reported the binuclear complexes of the 1-(pyridin-2-yl)-2-(pyridin-2ylmethylene)hydrazine ligand (HL) $\left[\mathrm{Ln}_{2}(\mathrm{HL})_{2}\left(\mathrm{CH}_{3} \mathrm{COO}\right)_{6}\right] \cdot \mathrm{n}\left(\mathrm{H}_{2} \mathrm{O}\right)(\mathrm{Ln}=\mathrm{Y}, \mathrm{Pr}, \mathrm{Gd}$ and Er). The binuclear complexes are characterized by IR and physical measurement. Spectroscopic evidence indicated that the Schiff base HL behave an $\mathrm{N}_{3}$ coordination tridentate ligand. The complexes are formulated as $[\{\operatorname{Ln}(1-($ pyridin-2-ylmethylidene- $\kappa N)$ 2-(pyridin-2-yl- $\kappa N)$ hydrazine- $\left.\left.\kappa N^{1}\right)\left(\eta^{2}-\mathrm{OOCH}_{3}\right)_{2}\right\}\left\{\eta^{1}: \eta^{2}: \mu_{2}-\mathrm{OOCH}_{3}\right\}_{2}\{\mathrm{Ln}(1-($ pyridin2-ylmethylidene- $\kappa N)$-2-(pyridin-2-yl- $\kappa N)$ hydrazine- $\left.\left.\left.\left.\kappa N^{1}\right)\right)\left(\eta^{2}-\mathrm{OOCH}_{3}\right)_{2}\right\}\right] \cdot \mathrm{n}\left(\mathrm{H}_{2} \mathrm{O}\right)$. The structure of the praseodymium complex was elucidated by X-ray diffraction analysis. Suitable crystals were grown by slow evaporation of methanol solution. The asymmetric unit of the compound contains two neutral ligand molecules, two $\operatorname{Pr}^{3+}$ ions, four acetate anions acting in $\eta^{2}-\mathrm{OOCH}_{3}$ mode, two acetate anions acting in $\eta^{1}: \eta^{2}: \mu_{2}-\mathrm{OOCH}_{3}$ mode, and three uncoordinated water molecules. The praseodymium atom is ten coordinated and the coordination sphere is best described as a distorted bicapped square antiprism. The $\operatorname{Pr}^{\mathrm{III}}$... $\mathrm{Pr}^{\mathrm{III}}$ distance is 4.2777(6) $\AA$ and the bridging angle $\mathrm{Pr}-\mathrm{O}-\mathrm{Pr}$ and $\mathrm{O}-\mathrm{Pr}-\mathrm{O}$ are respectively $115.8(3)^{\circ}$ and $64.2(3)^{\circ}$. The structure is consolidated by intra and intermolecular hydrogen bond.
\end{abstract}

\section{Received: November 24, 2021; Accepted: December 13, 2021}

Keywords and phrases: lanthanide; 2-hydrazinopyridine; 2-pyridinecarbaldehyde; X-ray structure.

Copyright (C) 2022 the authors. This is an open access article distributed under the Creative Commons Attribution License (http://creativecommons.org/licenses/by/4.0/), which permits unrestricted use, distribution, and reproduction in any medium, provided the original work is properly cited. 


\section{Introduction}

The coordination chemistry of lanthanide is largely investigated by chemist in the two last decades [1-5]. Indeed, a wide variety of compounds with intriguing structures and atypical properties are reported in recent years [6-8]. The potential use in fields such as medical diagnostics [9], catalysis [10,11], luminescence [12,13], or magnetism [14,15] is increasing the interest of researchers. Polydentate ligands containing different donor sites are developed to generate special topological structures with lanthanide ions [16]. Combined with co-ligands such as the acetate moiety, these ligands allow the preparation of polyvalent coordination compounds by meticulously controlling the process $[2,17]$. Indeed, the mode of coordination depends on the reaction conditions. Interest is given to ligands having both soft and hard donor sites such as sulfur, nitrogen, and oxygen. The complexation of these types of ligands with metal ions often improves the biological properties of the complexes relative to the free ligand $[18,19]$. Compounds obtained from hydrazone ligand have shown antioxidant, antitumor, antiviral, and anti-inflammatory activity. Several authors [20,21] have used ligand analogous to 1-(pyridin-2-yl)-2(pyridin-2-ylmethylene)hydrazine (HL) in the presence of acetate ions to prepare coordination compounds. Our group has already used this ligand in the presence of sodium acetate and hydrated lanthanide nitrate to prepare several complexes [22-25]. In all these complexes the acetate group is either bidentate chelating $\eta^{2}-\mathrm{OOCH}_{3}$ or bidentate bridging $\eta^{2}: \mu_{2}-\mathrm{OOCH}_{3}$. In the present study, a mixture of the HL ligand and hydrated lanthanide acetate gives a homo dinuclear complexes of lanthanide $\left(\mathrm{Y}^{3+}, \mathrm{Pr}^{3+}, \mathrm{Gd}^{3+}, \mathrm{Er}^{3+}\right)$ in which two modes of coordination of the acetate group are observed: $\eta^{2}-\mathrm{OOCH}_{3}$ and $\eta^{1}: \eta^{2}: \mu_{2}-\mathrm{OOCH}_{3}$. The structure of [ $\{\operatorname{Pr}(1$-(pyridin-2-ylmethylidene- $\mathrm{k} N)$-2-(pyridin-2-yl)$\kappa N)$ hydrazine- $\left.\left.\kappa N^{1}\right)\left(\eta^{2}-\mathrm{OOCH}_{3}\right)_{2}\right\}\left\{\eta^{1}: \eta^{2}: \mu_{2}-\mathrm{OOCH}_{3}\right\}_{2}\{[\{\operatorname{Pr}(1-($ pyridin-2-ylmethylidene$\kappa N)$-2-(pyridin-2-yl)- $\kappa N)$ hydrazine- $\left.\left.\left.\left.\kappa N^{1}\right)\left(\eta^{2}: \mathrm{OOCH}_{3}\right)_{2}\right\}\right\}\right] \cdot 3\left(\mathrm{H}_{2} \mathrm{O}\right)$ has been elucidated by $\mathrm{X}$-ray diffraction.

\section{Materials and Methods}

\subsection{Starting materials and instrumentations}

2-Hydrazinopyridine,2-pyridinecarboxaldehyde, and lanthanide acetate were purchased from Sigma-Aldrich and used as received without further purification. All solvents used were of reagent grade. The ligand (HL) was synthesized in situ. Elemental analyses of $\mathrm{C}, \mathrm{H}$ and $\mathrm{N}$ were recorded on a VxRio EL Instrument. Infrared spectra were obtained on a FTIR Spectrum Two of Perkin Elmer spectrometer in the $4000-400 \mathrm{~cm}^{-1}$ 
region. The molar conductance of $1 \times 10^{-3} \mathrm{M}$ in DMSO solutions of the metal complexes was measured at $25^{\circ} \mathrm{C}$ using a WTW LF-330 conductivity meter with a WTW conductivity cell. Room temperature magnetic susceptibilities of the powdered samples were measured using a Johnson Mattey scientific magnetic susceptibility balance (Calibrant: $\mathrm{Hg}[\mathrm{Co}(\mathrm{SCN}) 4])$.

\subsection{Synthesis and characterization of $1,2,3$ and 4}

A mixture of 2-hydrazinopyridine (1 mmol) and 2-pyridinecarbaldehyde (1 mmol) in ethanol $(15 \mathrm{~mL})$ was stirred under reflux during $30 \mathrm{~min}$. An ethanol solution of $\mathrm{Ln}\left(\mathrm{CH}_{3} \mathrm{OO}\right)_{3} \cdot \mathrm{nH}_{2} \mathrm{O}(1 \mathrm{mmol})(\mathrm{Ln}=\mathrm{Y}, \mathrm{Er} ; \mathrm{Gd}, \mathrm{Pr})$ in ethanol $(10 \mathrm{~mL})$ was added to the solution. The mixture was stirred for $30 \mathrm{~min}$ and the resulting yellow solution was filtered and the filtrate was kept at $298 \mathrm{~K}$. A yellow powder appeared after one day and was collected by filtration. Recrystallisation in methanol solution afforded suitable X-ray diffraction crystal of the complex or praseodymium.

$\left[\mathrm{Y}_{2}(\mathrm{HL})_{2}\left(\mathrm{OOCH}_{3}\right)_{6}\right] \cdot 2\left(\mathrm{H}_{2} \mathrm{O}\right)$ (1). Yield : 59\%. $\mathrm{C}_{34} \mathrm{H}_{48} \mathrm{~N}_{8} \mathrm{O}_{14} \mathrm{Y}_{2}$. Elemental Anal. Found (Calcd.) (\%):C, 42.07 (42.05); H, 4.98 (4.95); N, 11.54 (11.51).IR ( $\left.\mathrm{cm}^{-1}\right)$ :3425, $3290,1600,1582,1560,1448,1379,1134,1013,827 . \mu_{\text {eff }}\left(\mu_{\mathrm{B}}\right)$ : diamagnetic. $\Lambda_{\mathrm{M}}\left(\mathrm{S} \mathrm{cm}{ }^{2}\right.$ $\left.\mathrm{mol}^{-1}\right): 9$.

$\left[\mathrm{Pr}_{2}(\mathrm{HL})_{2}\left(\mathrm{OOCH}_{3}\right)_{6}\right] \cdot 3\left(\mathrm{H}_{2} \mathrm{O}\right)$ (2). Yield :69\%. $\mathrm{C}_{34} \mathrm{H}_{50} \mathrm{~N}_{8} \mathrm{O}_{15} \mathrm{Pr}_{2}$. Elemental Anal. Found (Calcd.) (\%):C, 37.37 (37.35); H, 4.61 (4.58); N, $10.26(10.23) . I R\left(\mathrm{~cm}^{-1}\right)$ :3420, $3292,1595,1580,1555,1445,1380,1143,1015,825 . \mu_{\text {eff }}\left(\mu_{\mathrm{B}}\right): 5.22 . \Lambda_{\mathrm{M}}\left(\mathrm{S} \mathrm{cm}^{2} \mathrm{~mol}^{-1}\right)$ : 25.

$\left[\mathrm{Gd}_{2}(\mathrm{HL})_{2}\left(\mathrm{OOCH}_{3}\right)_{6}\right] \cdot 4\left(\mathrm{H}_{2} \mathrm{O}\right)$ (3). Yield :48\%. $\mathrm{C}_{34} \mathrm{H}_{52} \mathrm{~N}_{8} \mathrm{O}_{16} \mathrm{Gd}_{2}$. Elemental Anal. Found (Calcd.) (\%):C, 35.72 (35.69); H, 4.58 (4.55); N, 9.80 (9.76).IR ( $\left.\mathrm{cm}^{-1}\right)$ :3429, $3288,1592,1580,1552,1440,1378,1143,1012,823 . \mu_{\text {eff }}\left(\mu_{\mathrm{B}}\right): 13.25 . \Lambda_{\mathrm{M}}\left(\mathrm{S} \mathrm{cm}^{2} \mathrm{~mol}^{-1}\right)$ $: 16$.

$\left[\mathrm{Er}_{2}(\mathrm{HL})_{2}\left(\mathrm{OOCH}_{3}\right)_{6}\right] \cdot 2\left(\mathrm{H}_{2} \mathrm{O}\right)$ (4). Yield :44\%. $\mathrm{C}_{34} \mathrm{H}_{48} \mathrm{~N}_{8} \mathrm{O}_{14} \mathrm{Er}_{2}$. Elemental Anal. Found (Calcd.) (\%):C, 36.22 (36.20); H, 4.29 (4.25); N, 9.94 (9.92).IR $\left(\mathrm{cm}^{-1}\right)$ :3412, $3285,1589,1578,1550,1435,1375,1143,1011,820 . \mu_{\text {eff }}\left(\mu_{\mathrm{B}}\right): 16.45 . \Lambda_{\mathrm{M}}\left(\mathrm{S} \mathrm{cm}^{2} \mathrm{~mol}^{-1}\right): 22$.

\subsection{X-ray crystallography}

Crystals suitable for single-crystal X-ray diffraction, of the $\operatorname{Pr}(\mathrm{III})$ complex, were grown by slow evaporation of $\mathrm{MeOH}$ solution of the compound. Details of the crystal structure solution and refinement are given in Table 1. Diffraction data were collected 
using an ENRAF NONIUS Kappa CCD diffractometer with graphite monochromatized MoK $\alpha$ radiation $(\lambda=0.71073 \AA$ ). All data were corrected for Lorentz and polarization effects. No absorption correction was applied. Complex scattering factors were taken from the program package SHELXTL [26]. The structures were solved by direct methods, which revealed the position of all non-hydrogen atoms. All the structures were refined on $F^{2}$ by a full-matrix least-squares procedure using anisotropic displacement parameters for all non-hydrogen atoms [27]. The hydrogen atoms of water molecules and $\mathrm{NH}$ groups were located in the Fourier difference maps and refined. Others $\mathrm{H}$ atoms $(\mathrm{CH}$ and $\mathrm{CH}_{3}$ groups) were geometrically optimized and refined as riding model by AFIX instructions. Molecular graphics were generated using ORTEP-3 [28].

\section{Results and Discussion}

\subsection{General study}

The strong band expected at $c a$. $1630 \mathrm{~cm}^{-1}$ due to $\mathrm{C}=\mathrm{N}$ for the free ligand is shifted to low frequencies and appears in the range $1600-1589 \mathrm{~cm}^{-1}$ in the spectra of 1-4. This is indicative of the involvement of the azomethine nitrogen atom in the coordination to the lanthanide ion. The bands located in the range $3285-3292 \mathrm{~cm}^{-1}$ in the spectra of the complexes 1-4 is attributed to the $\mathrm{N}-\mathrm{H}$ stretching vibrations. This band which is located at $3290 \mathrm{~cm}^{-1}$ in the spectrum of the free ligand remained unaffected upon coordination, precluding the non-involvement of this nitrogen atom in the coordination. The IR bands of the acetate groups in the spectra of the complexes are compared with those of the free acetic acid. The spectrum of the free acetic acid presents two mains bands at $1585 \mathrm{~cm}^{-1}$ and $1397 \mathrm{~cm}^{-1}$, which are attributed respectively to the $v_{\text {as }}(\mathrm{COO})$ and $v_{\mathrm{s}}(\mathrm{COO})$ stretching vibrations [2]. Upon coordination to lanthanide ion these bands were shifted. The $v_{\text {as }}(\mathrm{COO})$ shifted to high frequencies and are in the range $1578-1582 \mathrm{~cm}^{-1}$ for complexes 1-4. The symmetrical resonance split into two components. One band appears in higher frequency (1438-1145 $\mathrm{cm}^{-1}$ ) while the other bands appears at lower frequency (1375$1380 \mathrm{~cm}^{-1}$ ) comparatively to the $v_{\mathrm{s}}(\mathrm{COO})$ value of $1397 \mathrm{~cm}^{-1}$ in the free acetic acid. These observations are indicative of the presence of two different coordination modes of the acetate groups [29]. The presence of water molecules in whole complexes was proved by the strong and broad bands which appear in the range $3412-3429 \mathrm{~cm}^{-1}$. The $\mathrm{N}-\mathrm{N}$ band appears at $c a .1010 \mathrm{~cm}^{-1}$. The magnetic moment values of $5.22 \mu_{\mathrm{B}}, 13.25 \mu_{\mathrm{B}}$ and $16.45 \mu_{\mathrm{B}}$ for complexes $\mathbf{2}, \mathbf{3}$ and $\mathbf{4}$ respectively, show little deviation from the theoretical values reported for the trivalent lanthanide ions. This observation is indicative that the $4 \mathrm{f}$ 
electrons do not participate in the bond formation of the metal to the ligand. The molar conductivities of the complexes were measured in dimethylsulfoxide (dmso) for freshly prepared solutions and after standing for two weeks. No variation of the conductivities values is observed with time in dmso for all the complexes. This is indicative of high stability of these acetate complexes in dmso solutions. The values of these conductance are in the range $9-25 \mathrm{Ohm}^{-1} \mathrm{~cm}^{2} \mathrm{~mol}^{-1}$ in dmso and are in accordance with non-electrolytes nature of the complexes in this solvent [30]. These facts are in accordance with the infrared spectra where the compounds were formulated as neutral acetato complexes. The behaviors of the complexes in solid state are not different from the behaviors of the compounds in dmso the solution.
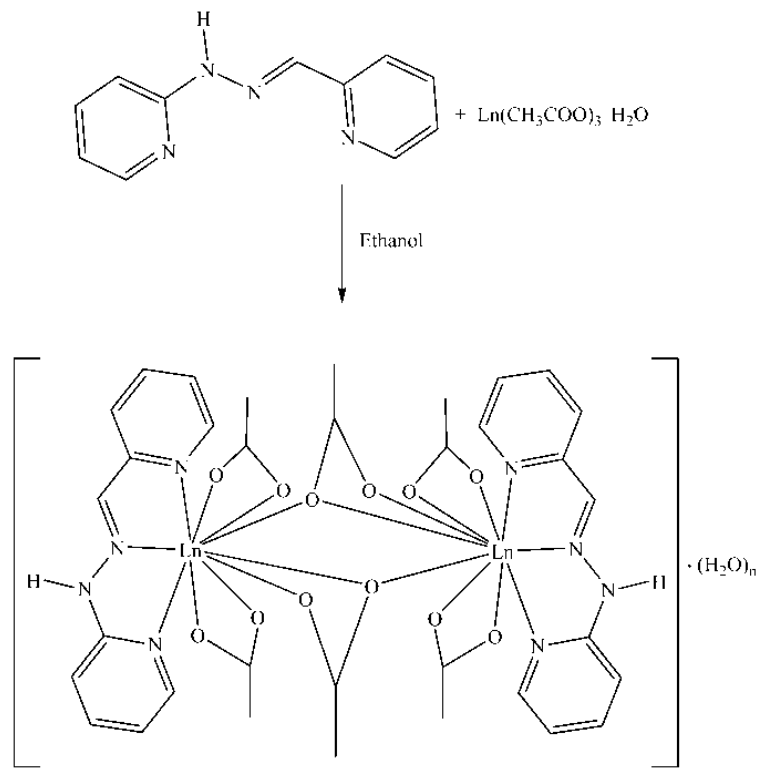

Scheme 1. Chemical diagrams for $\left[\mathrm{Ln}_{2}(\mathrm{HL})_{2}\left(\mathrm{CH}_{3} \mathrm{COO}\right)_{6}\right] \cdot n\left(\mathrm{H}_{2} \mathrm{O}\right)$.

\subsection{Molecular structure of complex 2}

The complex formulated as $[\{\operatorname{Pr}(1$-(pyridin-2-ylmethylidene- $k N)-2$-(pyridin-2-yl$\kappa N)$ hydrazine- $\left.\left.\kappa N^{1}\right) \quad\left(\eta^{2}-\mathrm{OOCH}_{3}\right)_{2}\right\} \quad\left\{\eta^{1}: \eta^{2}: \mu_{2}-\mathrm{OOCH}_{3}\right\}_{2} \quad\{\operatorname{Pr}(1$-(pyridin-2-ylmethylidene$\kappa N)$-2-(pyridin-2-yl- $\kappa N)$ hydrazine- $\left.\left.\left.\kappa N^{1}\right)\left(\eta^{2}-\mathrm{OOCH}_{3}\right)_{2}\right\}\right] \cdot \mathrm{n}\left(\mathrm{H}_{2} \mathrm{O}\right)(2)$ crystallizes in the triclinic system with a space group P-1. The crystal data collection and refinement are reported in Table 1. The ORTEP diagram of the structure of the binuclear complex is illustrated in Figure 1. Selected bonds lengths and angles are listed in Table 2. 


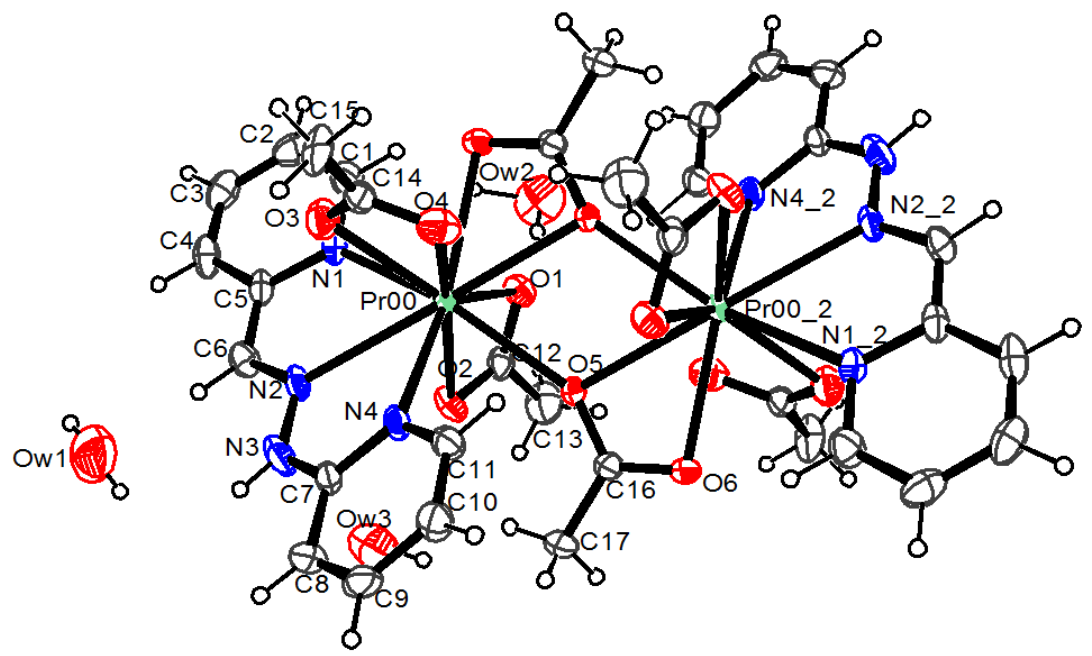

Figure 1. ORTEP Plot (30\% probability ellipsoids) showing the structure of the binuclear complex 2.

The acetato-bridged complex 2 displays a structure constructed from two identical entities $\left\{\operatorname{Pr}(1-(\right.$ pyridin-2-ylmethylidene- $\kappa N)-2$-(pyridin-2-yl)- $\kappa N)$ hydrazine- $\left.\kappa N^{1}\right) \quad\left(\eta^{2}-\right.$ $\left.\left.\mathrm{OOCH}_{3}\right)_{2}\right\}$ bridged by two acetateanions acting in $\eta^{1}: \eta^{2}: \mu_{2}-\mathrm{OOCH}_{3}$ modes, yielding a dinuclear neutral complex. Each $\mathrm{Pr}^{\mathrm{III}}$ ions is coordinated by one HL ligand through two 2pyridyl nitrogen atoms and one imino nitrogen atom. Additionally, each $\operatorname{Pr}^{\mathrm{III}}$ ion is coordinated by two chelating-bidentate acetate groups acting in $\eta^{2}-\mathrm{OOCH}_{3}$ mode. The $\mathrm{Pr}-\mathrm{O}$ distances are in the range 2.507 (7) —2.684 (8) $\AA$ and are typical of a chelatingbidentate acetate group [31]. The two metal centers are finally bridged by a pair of chelating-bridging acetato ligands which are acting in $\eta^{1}: \eta^{2}: \mu_{2}-\mathrm{OOCH}_{3}$ (Figure 2a). Two different bonds values are noted: two typical bond values of 2.465 (6) $\AA$ (Pr00i - O5) and 2.531 (7) $\AA$ (Pr00-O6) which are shorter than the non-typical bond distance of 2.583 (6) $\AA$ (Pr00 - O5) which is indicative of a weak bond character. These values are comparable to values noted from literature [32]. The largest $\mathrm{Pr}-\mathrm{O}(\mathrm{Pr} 00-\mathrm{O} 4=2.684$ (8) $\AA$ ) distance is observed in the chelating coordination mode $\eta^{2}-\mathrm{OOCH}_{3}$, while the shortest $\mathrm{Pr}-\mathrm{O}\left(\mathrm{Pr} 00-\mathrm{O} 5^{\mathrm{i}}=2.465(6) \AA\right)$ bond length is observed in the chelatingbridging coordination mode $\eta^{1}: \eta^{2}: \mu_{2}-\mathrm{OOCH}_{3}$. The $\mathrm{Pr}-\mathrm{N}$ distances are 2.632 (8) $\mathrm{A}, 2.661$ (8) $\AA$ and $2.688(8) \AA$. The longest $\mathrm{Pr}-\mathrm{N}$ distance is due to the nitrogen atom belonging to the ortho-hydrazino substituted pyridine ring, as observed for similar complexes [22]. The $\mathrm{C}-\mathrm{O}$ bond in the coordinated acetate groups has an intermediate character between single $\mathrm{C}-\mathrm{O}$ bond and double $\mathrm{C}=\mathrm{O}$ bond. In fact, the bond lengths values observed in 
both coordinated acetate groups for $\mathrm{C}-\mathrm{O}[1.232$ (11) $\AA$-1.286 (12) $\AA$ ] are shorter than those of a single $\mathrm{C}-\mathrm{O}$ bond (1.430 $\AA$ ) and longer than those of a double bond (1.220 $\mathrm{A}$ ). The N2-C6 bond length value of 1.338(13) $\AA$ is consistent with double bond character. The Pr $\cdots \operatorname{Pr}$ distance is 4.2777 (6) $\AA$. All the bond lengths are normal and fall within similar ranges to those reported for dinuclear lanthanide complexes with the same hydrazone ligand $[22,23]$. The chelation of the hydrazino ligand to the $\operatorname{Pr}^{\mathrm{III}}$ cation results in two five-membered rings (PrNCNN and PrNCCN) with bite angles of 60.3(3) ${ }^{\circ}(\mathrm{N} 1-$ Pr00-N2) and 59.6(3) (N2-Pr00-N4). The bond angles of the ligands, which involve the $\operatorname{Pr}(\mathrm{III})$ ion, are slightly largest than the angle subtended by the oxygen atoms of the bidentate chelating acetate groups :O3-Pr00-O $4=48.39(3)^{\circ}$ and O5-Pr00-O6 $=50.2(2)^{\circ}$. These angle values are comparable to the values reported for the complex $\left[\mathrm{Pr}\left(\mathrm{C}_{9} \mathrm{H}_{4} \mathrm{~N}_{2} \mathrm{O}_{4}\right)\left(\mathrm{C}_{2} \mathrm{H}_{3} \mathrm{O}_{2}\right)\left(\mathrm{H}_{2} \mathrm{O}\right)\right]_{\mathrm{n}}$ [31]. The bond angle value of $64.2(3)^{\circ}$ of the bridged oxygen atoms of the $\eta^{1}: \eta^{2}: \mu_{2}$-acetate groups [O5-Pr00-O $\left.5^{\mathrm{i}}\right]$ is comparable with the angle value observed in homologous complex of $\left[\mathrm{Tb}_{2}\left(\mathrm{CH}_{3} \mathrm{COO}\right)_{6}\left(\mathrm{H}_{2} \mathrm{O}\right)_{4}\right] \cdot 4 \mathrm{H}_{2} \mathrm{O}$ [33]. The value of $115.8(3)^{\circ}$ of the bridging angle $\mathrm{Pr} 00-\mathrm{O} 5-\mathrm{Pr} 00$ is in the range expected for $\eta^{1}: \eta^{2}: \mu_{2}$-acetate groups [2]. The dihedral angle formed by the planes of the two terminal pyridine rings is $15.61^{\circ}$. The coordination sphere around the ten-coordinated praseodymium atom is best described as a distorted bicapped square antiprism in which $\mathrm{N} 2$ and $\mathrm{O} 5$ are the caps as shown in Figure 2b. Numerous intra and inter molecular hydrogen bonds (Table 3, Figure 3) consolidate the structure in a three-dimensional network (Figure 4).
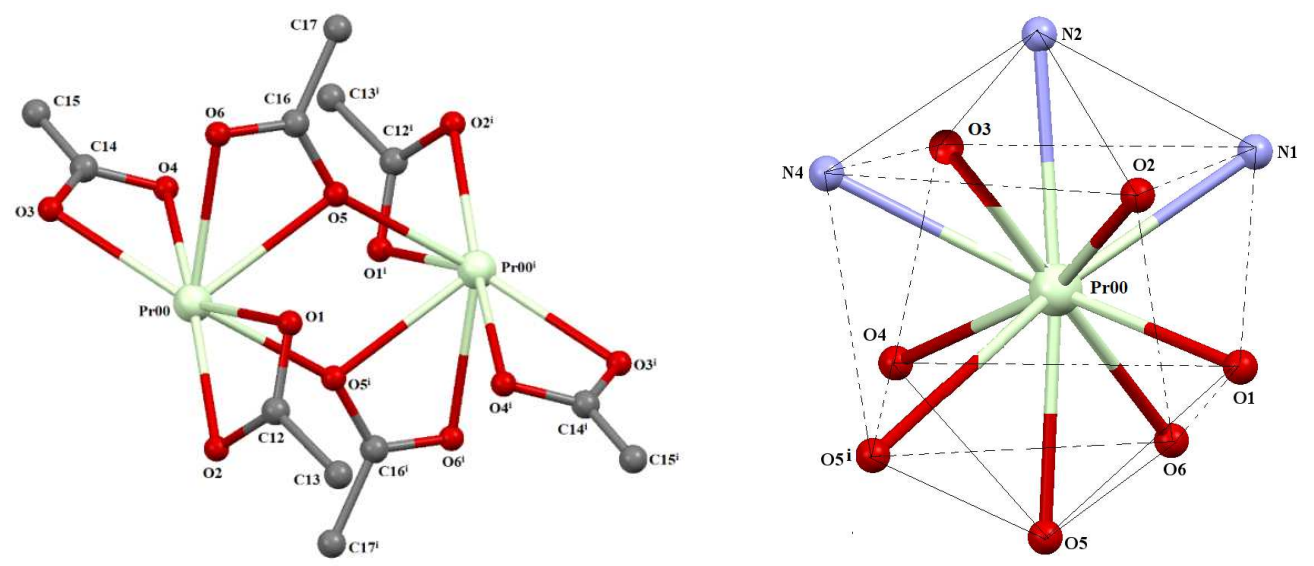

Figure 2. Plot showing the bridging mode of the acetate group (a) and the coordination sphere around the $\operatorname{Pr}^{\mathrm{III}}$ ion in the crystal (b). 
Table 1. Crystal data, X-ray data collection, data reduction and structure refinement for $\mathbf{2}$.

\begin{tabular}{|c|c|}
\hline Chemical formula & $\mathrm{C}_{34} \mathrm{H}_{50} \mathrm{Pr}_{2} \mathrm{~N}_{8} \mathrm{O}_{15}$ \\
\hline$M_{\mathrm{r}}$ & 1092.62 \\
\hline Crystal system, space group & Triclinic, $P-1$ \\
\hline Temperature (K) & 293 \\
\hline$a, b, c(\AA)$ & $9.4073(6), 10.8511(5), 11.6136(4)$ \\
\hline$\alpha, \beta, \gamma\left(^{\circ}\right)$ & $103.521(4), 98.235(4), 107.875(5)$ \\
\hline$V\left(\AA^{3}\right)$ & $1066.99(10)$ \\
\hline$Z$ & 5 \\
\hline Calculated density $\left(\right.$ g.cm $\left.{ }^{-3}\right)$ & 1.559 \\
\hline $\mathrm{F}(000)$ & 514 \\
\hline Radiation type & $\lambda=0.71073 \AA$ \\
\hline$\mu\left(\mathrm{mm}^{-1}\right)$ & 1.20 \\
\hline Crystal size (mm) & $0.15 \times 0.10 \times 0.08$ \\
\hline \multicolumn{2}{|l|}{ Data collection } \\
\hline Diffractometer & XtaLAB AFC12 (RCD3): Kappa single \\
\hline Absorption correction & Multi-scan \\
\hline$T_{\min } \cdot T_{\max }$ & $0.893 ; 1.000$ \\
\hline \multicolumn{2}{|l|}{ Limiting indices } \\
\hline $\mathrm{h}$ & $-11 \rightarrow 11$ \\
\hline $\mathrm{k}$ & $-13 \rightarrow 13$ \\
\hline 1 & $-11 \rightarrow 13$ \\
\hline $\begin{array}{l}\text { No. of measured, independent and } \\
\text { observed }[\underline{I>2 \sigma(I)}] \text { reflections }\end{array}$ & $7523,3570,2886$ \\
\hline$R_{\text {int }}$ & 0.113 \\
\hline \multicolumn{2}{|l|}{ Refinement } \\
\hline$R\left[F^{2}>2 \sigma\left(F^{2}\right)\right], w R\left(F^{2}\right), S$ & $0.067,0.190,1.05$ \\
\hline No. of reflections & 3570 \\
\hline No. of parameters/restraints & $296 / 0$ \\
\hline $\mathrm{H}$-atom treatment & $\begin{array}{l}\mathrm{H} \text { atoms treated by a mixture of independent and } \\
\text { constrained refinement }\end{array}$ \\
\hline$\Delta \rho_{\max } \cdot \Delta \rho_{\min }\left(\mathrm{e} \AA^{-3}\right)$ & $1.95 \&-2.51$ \\
\hline
\end{tabular}


Table 2. Selected bond lengths $(\AA)$ and angles $\left({ }^{\circ}\right)$ for the complex 2.

\begin{tabular}{|c|c|c|c|}
\hline Bond & bond lengths [̊̊] & Bond & bond angles $\left({ }^{\circ}\right)$ \\
\hline $\mathrm{Pr} 00-\mathrm{O} 5$ & $2.465(6)$ & $\mathrm{O} 5-\mathrm{Pr} 00-\mathrm{O} 6^{\mathrm{i}}$ & $113.9(2)$ \\
\hline $\mathrm{Pr} 00-\mathrm{O} 2$ & $2.504(7)$ & $\mathrm{O} 2-\mathrm{Pr} 00-\mathrm{O} 1$ & $51.6(2)$ \\
\hline $\operatorname{Pr} 00-06^{i}$ & $2.531(7)$ & $\mathrm{N} 1-\mathrm{Pr} 00-\mathrm{N} 2$ & $60.3(3)$ \\
\hline $\mathrm{Pr} 00-\mathrm{O} 1$ & $2.539(7)$ & $\mathrm{O} 3-\mathrm{Pr} 00-\mathrm{O} 4$ & $48.3(3)$ \\
\hline $\mathrm{Pr} 00-\mathrm{O} 3$ & $2.542(8)$ & N2-Pr00-N4 & $59.6(3)$ \\
\hline $\mathrm{Pr} 00-O 5^{\mathrm{i}}$ & $2.583(6)$ & $\operatorname{Pr} 00-O 5-\operatorname{Pr} 00^{i}$ & $115.8(3)$ \\
\hline Pr00-N1 & $2.632(8)$ & $\mathrm{O} 5-\mathrm{Pr} 00-\mathrm{O}^{\mathrm{i}}$ & $64.2(3)$ \\
\hline $\mathrm{Pr} 00-\mathrm{N} 2$ & $2.661(8)$ & $\mathrm{O} 5-\mathrm{Pr} 00-\mathrm{O} 6$ & $50.2(2)$ \\
\hline $\mathrm{Pr} 00-\mathrm{O} 4$ & $2.684(8)$ & & \\
\hline $\mathrm{Pr} 00-\mathrm{N} 4$ & $2.688(8)$ & & \\
\hline
\end{tabular}

Symmetry Codes: (i) $-\mathrm{x}+1,-\mathrm{y}+1,-\mathrm{z}+1$

Table 3. Hydrogen-bond geometry $\left(\AA{ }^{\circ}{ }^{\circ}\right)$

\begin{tabular}{|c|c|c|c|c|}
\hline$D-\mathbf{H} \cdots A$ & $D-\mathbf{H}$ & $\mathbf{H} \cdots A$ & $D \cdots A$ & $D-\mathbf{H} \cdots A$ \\
\hline Ow1-Hw1A ‥ Ow3 & 0.85 & 2.05 & $2.77(2)$ & 143 \\
\hline Ow1-Hw1B ‥ Ow2 & 0.85 & 1.92 & $2.75(3)$ & 163 \\
\hline $\mathrm{Ow} 2-\mathrm{Hw} 2 \cdots \mathrm{O} 1$ & 0.85 & 2.04 & $2.879(18)$ & 168 \\
\hline Ow3-Hw3A… Ow1 & 0.85 & 2.19 & $2.77(2)$ & 125 \\
\hline $\mathrm{C} 1-\mathrm{H} 1 \cdots \mathrm{O} 6$ & 0.93 & 2.55 & $3.157(13)$ & 123 \\
\hline $\mathrm{C} 2-\mathrm{H} 2 \cdots \mathrm{Ow} 3$ & 0.93 & 2.37 & $3.25(2)$ & 158 \\
\hline 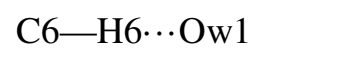 & 0.93 & 2.14 & $3.06(2)$ & 171 \\
\hline $\mathrm{C} 11-\mathrm{H} 11 \cdots \mathrm{O} 1$ & 0.93 & 2.52 & $3.429(13)$ & 165 \\
\hline C15-H15C ‥ Ow1 & 0.96 & 2.33 & $2.87(3)$ & 115 \\
\hline $\mathrm{C} 15-\mathrm{H} 15 \mathrm{C} \cdots \mathrm{N} 3$ & 0.96 & 2.57 & $3.269(17)$ & 130 \\
\hline
\end{tabular}




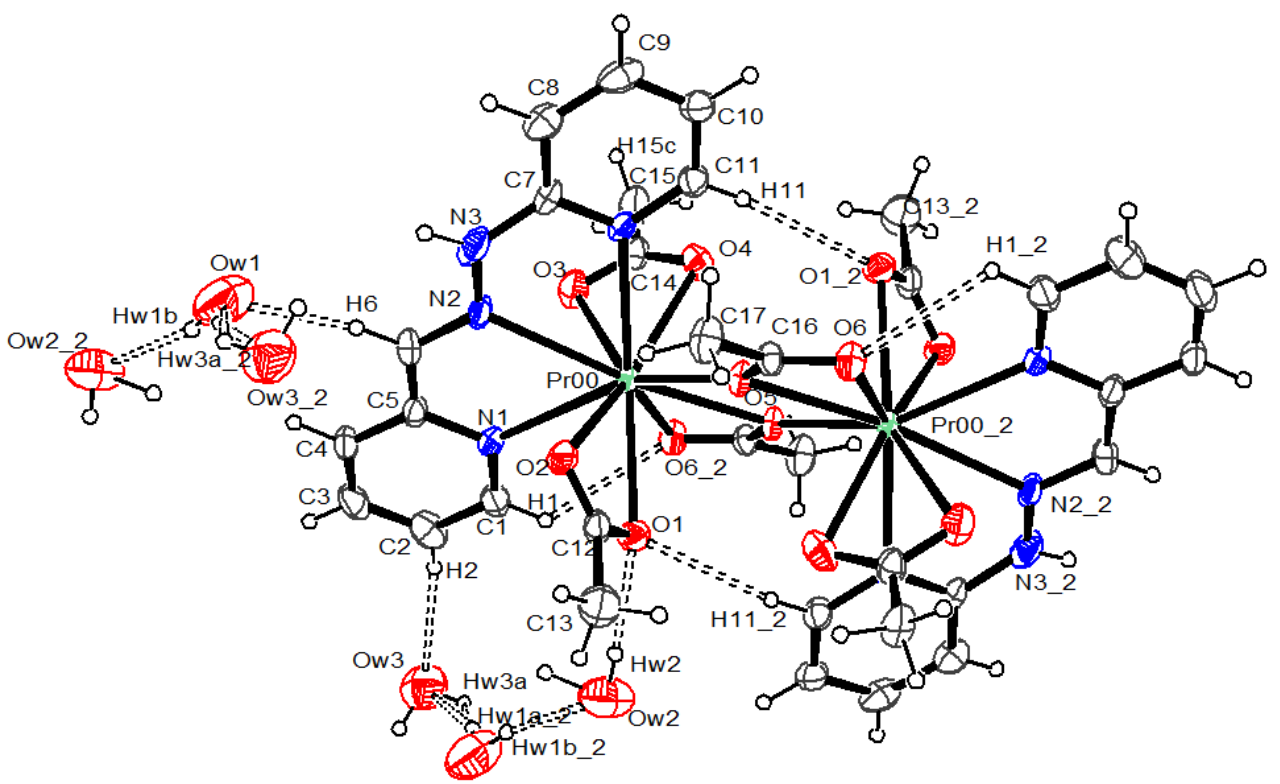

Figure 3. Plot showing the inter and intramolecular hydrogens bonds in the crystal.

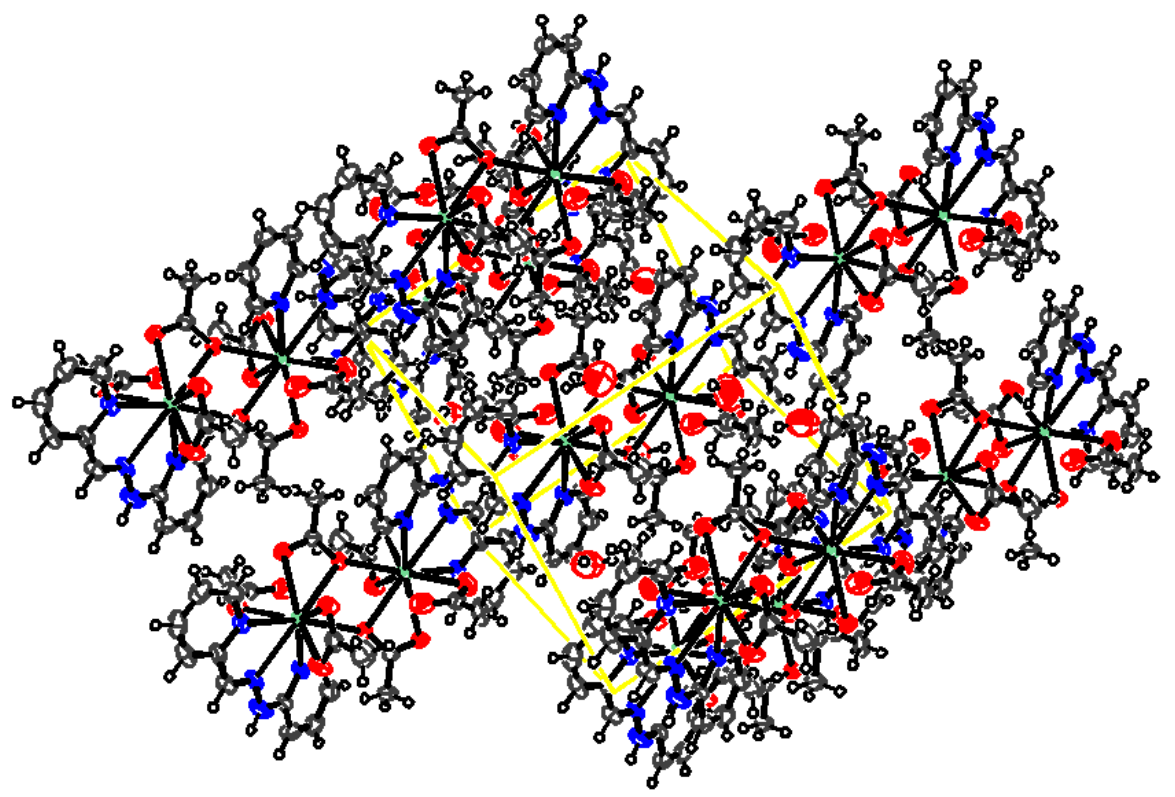

Figure 4. The packing of the complex 2 in the crystal structure. 


\section{Conclusion}

In summary, we have successfully synthesized and studied the homo binuclear complexes containing Ln (III) ions. A suitable crystal of the complex was obtained by slow evaporation of methanol solution of the $\operatorname{Pr}^{3+}$ complex. Infrared spectra of the compounds were discussed in this paper. Crystal data, X-ray data collection, data reduction and structure refinement are studied for the $\operatorname{Pr}^{3+}$ complex. The binuclear complex crystallizes in the triclinic system with a space group P-1. The acetate groups act in two different coordination modes $: \eta^{2}-\mathrm{OOCH}_{3}$ and $\eta^{1}: \eta^{2}: \mu_{2}-\mathrm{OOCH}_{3}$. The environments of the ten-coordinated praseodymium (III) ions are best distorted as a distorted bicapped square antiprism. The structure of the complex is consolidated by numerous hydrogen bond.

\section{Supplementary Materials}

CCDC-2122385 contains the supplementary crystallographic data for this paper. These data can be obtained free of charge via https://www.ccdc.cam.ac.uk/structures/, or by e-mailing data_request@ccdc.cam.ac.uk, or by contacting The Cambridge Crystallographic Data Centre, 12 Union Road, Cambridge CB2 1EZ, UK; fax: $+44(0) 1223-336033$.

\section{Conflicts of Interest}

The authors declare no conflict of interest.

\section{Acknowledgements}

The authors thank the FONDATION SONATEL for his financial support. http://fondationsonatel.sn/.

\section{References}

[1] Anastasiadis, N.C., Mylonas-Margaritis, I., Psycharis, V., Raptopoulou, C.P., Kalofolias, D.A., Milios, C.J., Klouras, N., \& Perlepes, S.P. (2015). Dinuclear, tetrakis(acetato)bridged lanthanide(III) complexes from the use of 2-acetylpyridine hydrazone. Inorganic Chemistry Communications, 51, 99-102. https://doi.org/10.1016/j.inoche.2014.11.004

[2] Madanhire, T., Davids, H., Pereira, M.C., Hosten, E.C., \& Abrahams, A. (2020). Synthesis, characterisation and anticancer activity screening of lanthanide(III) acetate complexes with benzohydrazone and nicotinohydrazone ligands. Polyhedron, 184, 114560. https://doi.org/10.1016/j.poly.2020.114560 
[3] Soliman, S.M., \& El-Faham, A. (2018). Low temperature X-ray structure analyses combined with NBO studies of a new heteroleptic octa-coordinated Holmium(III) complex with N,N,N-tridentate hydrazono-phthalazine-type ligand. Journal of Molecular Structure, 1157, 222-229. https://doi.org/10.1016/j.molstruc.2017.12.016

[4] Li, H.-G., Yang, Z.-Y., Wang, B.-D., \& Wu, J.-C. (2010). Synthesis, crystal structure, antioxidation and DNA-binding properties of the Ln complexes with 1-phenyl-3-methyl5-hydroxypyrazole-4-carbaldhyde-(benzoyl)hydrazone. Journal of Organometallic Chemistry, 695, 415-422. https://doi.org/10.1016/j.jorganchem.2009.10.032

[5] Mohanan, K., Kumari, B.S., \& Rijulal, G. (2008). Microwave assisted synthesis, spectroscopic, thermal, and antifungal studies of some lanthanide(III) complexes with a heterocyclic bishydrazone. Journal of Rare Earths, 26, 16-21.

https://doi.org/10.1016/S1002-0721(08)60028-9

[6] Guskos, N., Typek, J., Majszczyk, J., Maryniak, M., \& Paschalidis, D. (2008). Photoacoustic spectrum of a new, 12-fold-coordinated Ho(III) hydrazone complex. Journal of Non-Crystalline Solids, 354, 4393-4395.

https://doi.org/10.1016/j.jnoncrysol.2008.06.057

[7] Ay, B., Yildiz, E., Şahin, O., Mahmoudi, G., Kubicki, M., Perumal, V., Percino, J., Miroslaw, B., \& Safin, D.A. (2020). Novel lanthanide(III) complex $\left[\mathrm{LaL}_{2}\left(\mathrm{NO}_{3}\right)\left(\mathrm{H}_{2} \mathrm{O}\right)_{2}\right] \cdot 5 \mathrm{H}_{2} \mathrm{O}$ with 2-pyridine carboxaldehyde isonicotinoyl hydrazine exhibiting a 3D supramolecular topology 3,6T49. Journal of Molecular Structure, 1212, 128151. https://doi.org/10.1016/j.molstruc.2020.128151

[8] Fang, M., Chen, Y.-Y., Shao, L.-J., Shi, T.-X., Yu, H., Li, P.-F., Wu, Z.-L., \& Wang, W.M. (2019). Structures, luminescent and magnetic properties of three dinuclear lanthanide complexes: Dysprosium compound displaying slow magnetic relaxation. Polyhedron, 157, 530-535. https://doi.org/10.1016/j.poly.2018.10.046

[9] Hosseini, M.-S., Amjadi, I., Mohajeri, M., Iqbal, M.Z., Wu, A., \& Mozafari, M. (2019). Chapter 15 - Functionalized polymers for diagnostic engineering, In M. Mozafari, N.P.S. Chauhan (Eds.), Advanced Functional Polymers for Biomedical Applications (pp. 301322). Elsevier. https://doi.org/10.1016/B978-0-12-816349-8.00015-1

[10] Taha, Z.A., Hijazi, A.K., \& Momani, W.M.A. (2020). Lanthanide complexes of the tridentate Schiff base ligand salicylaldehyde-2-picolinoylhydrazone: Synthesis, characterization, photophysical properties, biological activities and catalytic oxidation of aniline. Journal of Molecular Structure, 1220, 128712.

https://doi.org/10.1016/j.molstruc.2020.128712

[11] Lekha, L., Raja, K.K., Rajagopal, G., \& Easwaramoorthy, D. (2014). Schiff base 
complexes of rare earth metal ions: Synthesis, characterization and catalytic activity for the oxidation of aniline and substituted anilines. Journal of Organometallic Chemistry, 753, 72-80. https://doi.org/10.1016/j.jorganchem.2013.12.014

[12] Yuan, B., Wang, F., Tao, J., Li, M., \& Yang, X. (2019). Self-assembly of one visible and NIR luminescent Sm(III) coordination polymer with flexible Schiff base ligand. Inorganica Chimica Acta, 490, 24-28. https://doi.org/10.1016/j.ica.2019.02.019

[13] Yuan, B., Tao, J., Wang, F., Zhu, C., Li, M., \& Yang X., (2020). Construction of NIR luminescent nanoscale lanthanide complexes with new flexible Schiff base ligands. Journal of Rare Earths, 38, 143-147. https://doi.org/10.1016/j.jre.2019.02.014

[14] Yang, H., Liu, S.-S., Meng, Y.-S., Zhang, Y.-Q., Pu, L., \& Yu, X.-Q. (2019). Magnetic properties and theoretical calculations of mononuclear lanthanide complexes with a Schiff base coordinated to $\mathrm{Ln}(\mathrm{III})$ ion in a monodentate coordination mode. Inorganica Chimica Acta, 494, 8-12. https://doi.org/10.1016/j.ica.2019.04.051

[15] Ge, Y., Huang, Y., Wang, G., Li, Y., \& Yao, J. (2020). A series of mononuclear lanthanide complexes constructed by Schiff base and $\beta$-diketonate ligands: synthesis, structures, magnetic and fluorescent properties. Polyhedron, 187, 114651.

https://doi.org/10.1016/j.poly.2020.114651

[16] Binnemans, K. (2005). Chapter 225 - Rare-earth beta-diketonates, In K.A. Gschneidner, J.-C.G. Bünzli, V.K. Pecharsky (Eds.), Handbook on the Physics and Chemistry of Rare Earths (pp. 107-272). Elsevier. https://doi.org/10.1016/S0168-1273(05)35003-3

[17] Murase, M., Yamauchi, S., Sakamoto, S., Takahashi, S., Matsumoto, N., Tsuchimoto, M. (2013). Enantioselective aggregation and luminescence properties of europium(III) and terbium(III) complexes of an acetate and a tripodal ligand containing three imidazole groups. Polyhedron, 59, 76-84. https://doi.org/10.1016/j.poly.2013.04.040

[18] Di, Y., Cui, X., Liu, Y., Zhou, C., Ren, Y., Di, Y., Yang, X. (2019). Crystal structure, optical properties, and antibacterial activity of rare earth complexes with designed 2carbonyl propionic acid-4-nitro benzoyl hydrazone. Polyhedron, 171, 571-577. https://doi.org/10.1016/j.poly.2019.07.036

[19] Mohanan, K., Aswathy, R., Nitha, L.P., Mathews, N.E., Kumari, B.S. (2014). Synthesis, spectroscopic characterization, DNA cleavage and antibacterial studies of a novel tridentate Schiff base and some lanthanide(III) complexes. Journal of Rare Earths, 32, 379-388. https://doi.org/10.1016/S1002-0721(14)60081-8

[20] Neves, A., Erthal, S.M.D., Vencato, I., Ceccato, A.S., Mascarenhas, Y.P., Nascimento, O.R., Horner, M., \& Batista, A.A. (1992). Synthesis, crystal structure, electrochemical, and spectroelectrochemical properties of the new manganese(III) complex 
$\left[\mathrm{Mn}^{\mathrm{III}}(\mathrm{BBPEN})\right]\left[\mathrm{PF}_{6}\right] \quad\left[\mathrm{H}_{2} \mathrm{BBPEN} \quad=\quad\right.$ N,N'-bis(2-hydroxybenzyl)-N,N'-bis(2methylpyridyl)ethylenediamine]. Inorganic Chemistry, 31, 4749-4755.

https://doi.org/10.1021/ic00049a008

[21] Gregório, T., Rüdiger, A.L., Nunes, G.G., Soares, J.F., \& Hughes, D.L. (2015). Crystal structure of an eight-coordinate terbium(III) ion chelated by N,N'-bis-(2-hydroxybenzyl)N,N'-bis-(pyridin-2-ylmethyl) ethylenediamine $\left(\right.$ bbpen $\left.^{2-}\right)$ and nitrate. Acta Crystallographica E, 71, 65-68. https://doi.org/10.1107/S2056989014026826

[22] Ndiaye-Gueye, M., Dieng, M., Thiam, E.I., Lo, D., Barry, A.H., Gaye, M., \& Retailleau, P. (2017). Lanthanide(III) Complexes with Tridentate Schiff Base Ligand, Antioxidant Activity and X-Ray Crystal Structures of the $\mathrm{Nd}(\mathrm{III})$ and $\mathrm{Sm}(\mathrm{III})$ Complexes. South African Journal of Chemistry, 70, 8-15.

http://dx.doi.org/10.17159/0379-4350/2017/v70a2

[23] Gueye, Nd. M., Moussa, D., Thiam, E.I., Barry, A.H., Gaye, M., \& Retailleau, P. (2017). Crystal structure of bis-(acetato- $\left.\kappa^{2} O, O^{\prime}\right)$ diaqua[1-(pyridin-2-ylmethylidene- $\left.\kappa N\right)$-2(pyridin-2-yl- $\kappa N$ )hydrazine- $\left.\kappa N^{1}\right]$ terbium(III) nitrate monohydrate. Acta Crystallographica E, 73, 1121-1124. https://doi.org/10.1107/S2056989017009653

[24] Gueye, M.N., Dieng, M., Lo, D., Thiam, I.E., Barry, A.H., Gaye, M., Sall, A.S., \& Retailleau, P. (2017). Synthesis, physical studies and crystal structure determination of Y(III) and Er(III) complexes of 1-(pyridin-2-yl)-2-(pyridine-2-ylmethylene)hydrazine. European Journal of Chemistry, 8, 137-143.

https://doi.org/10.5155/eurjchem.8.2.137-143.1557

[25] Ndiaye-Gueye, M., Dieng, M., Thiam, I.E., Sow, M.M., Sylla-Gueye, R., Barry, A.H., Gaye, M., \& Retailleau, P. (2017). Synthesis, characterization and antioxidant activity of lanthanide (III) complexes with tridentate Schiff base ligand. X-ray crystal structure of the Ce(III) complex. Revue Roumaine de Chimie, 62, 35-41.

http://revroum.lew.ro/wp-content/uploads/2017/1/Art\%2005.pdf

[26] Sheldrick, G.M. (2015). SHELXT - Integrated space-group and crystal-structure determination. Acta Crystallographica A, 71, 3-8.

https://doi.org/10.1107/S2053273314026370

[27] Sheldrick, G.M. (2015). Crystal structure refinement with SHELXL. Acta Crystallographica C, 71, 3-8. https://doi.org/10.1107/S2053229614024218

[28] Farrugia, L.J. (2012). WinGX and ORTEP for Windows: an update. Journal of Applied Crystallography, 45, 849-854. https://doi.org/10.1107/S0021889812029111

[29] Nakamoto, K. (1986). Infrared spectra of inorganic and coordination compounds (4th ed.). New York: John Wiley \& Sons Inc. 
[30] Geary, W.J. (1971). The use of conductivity measurements in organic solvents for the characterization of coordination compounds. Coordination Chemistry Reviews, 7, 81-122. https://doi.org/10.1016/S0010-8545(00)80009-0

[31] Pan, Z.-Y., Chen, J.-H., Lin, J.-F., Xu, X., \& Luo, Y.-F. (2010). Poly[(acetato- $\left.{ }^{2} O, O^{\prime}\right)$ aqua $\left(\mu_{4}-1-\mathrm{H}\right.$-benzimidazole-5,6-dicarboxylato- $\left.\kappa^{5} N^{3}: O^{5}, O^{5}: O^{5}, O^{6}: O^{6}\right) \quad$ praseodymium(III)]. Acta Crystallographica E, 66, m1302. https://doi.org/10.1107/S1600536810036986

[32] Zhang, S.-Y., Shi, Z., Long-Guan, Z., Xu, R.-R., \& Pang, W.-Q. (2003). Di- $\mu$-acetato$\kappa^{3} O, O^{\prime}: O^{\prime}$-di- $\mu$-trichloroacetato- $\kappa^{2} O: O^{\prime}$-bis [aqua(trichloroacetato) $(1,10$-phenanthroline$\left.\kappa^{2} N, N^{\prime}\right)$ praseodymium(III)] dimethylformamide disolvate. Acta Crystallographica E, 59, m142-m144. https://doi.org/10.1107/S1600536803004744

[33] Yu, Q., Zhou, X., Liu, M., Chen, J., Zhou, Z., Yin, X., \& Cai Y. (2008). Syntheses, characterization, and luminescence of two lanthanide complexes [ $\operatorname{Ln}_{2}(\text { acetate })_{6}$ $\left.\left(\mathrm{H}_{2} \mathrm{O}\right)_{4}\right] \cdot 4 \mathrm{H}_{2} \mathrm{O}(\mathrm{Ln}=\mathrm{Tb}(1), \mathrm{Sm}(2))$. Journal of Rare Earths, 26, 178-184.

https://doi.org/10.1016/S1002-0721(08)60061-7 